\title{
I 57 Renal artery stenosis: independent predictor of increased mortality in patients with heart failure. A Magnetic Resonance Imaging study
}

\author{
Christos V Bourantas*1, Huan P Loh ${ }^{1}$, Ramesh de Silva ${ }^{1}$, Elena Lukaschuk ${ }^{1}$, \\ Tony Nicoslon², David Eadington ${ }^{3}$, Simon Thackray ${ }^{1}$, Ann C Thackray ${ }^{1}$, \\ Andrew L Clark ${ }^{1}$, Nikolay P Nikitin ${ }^{1}$ and John GF Cleland ${ }^{1}$
}

Address: ${ }^{1}$ Hull University, Hull, UK, ${ }^{2}$ Leeds General Infirmary, Leeds, UK and ${ }^{3}$ Hull Royal Infirmary, Hull, UK

* Corresponding author

from I th Annual SCMR Scientific Sessions

Los Angeles, CA, USA. I-3 February 2008

Published: 22 October 2008

Journal of Cardiovascular Magnetic Resonance 2008, I0(SuppI I):A58 doi:10.I I86/1532-429X-I0-SI-A58

This abstract is available from: http://jcmr-online.com/content/I0/SI/A58

(c) 2008 Bourantas et al; licensee BioMed Central Ltd.

\section{Introduction}

It is well known that renal artery stenosis (RAS) is associated with renal dysfunction and suboptimal heart failure (HF) treatment.

\section{Purpose}

To investigate the prevalence and of RAS and its prognostic impact in HF patients who are on optimal treatment with ACE inhibitors and b-blockers

\section{Methods}

234 patients with HF and on optimal treatment underwent cardiac and renal magnetic resonance imaging (MRI) examination. The renal MRI data were reviewed offline by an expert observer who identify the presence and severity of RAS. Patients were divided in 3 groups: A (normal renal arteries or RAS $<50 \%$ ), B (unilateral RAS > $50 \%$ ) and C (bilateral RAS > 50\%).

\section{Results}

The number of patients in A, B and C were 133, 62 and 39 respectively. The mean age was $70 \pm 10$ years and $81 \%$ were men. Mean EF was $38 \pm 14 \%$.

Patients from group $\mathrm{B}$ and $\mathrm{C}$ were older comparing to patients form group A $(73 \pm 8$ and $74 \pm 9$ vs. $67 \pm 11$, p < $0.0001)$, had lower GFR $(45 \pm 19 \mathrm{ml} / \mathrm{min}$ and $40 \pm 18$ $\mathrm{mil} / \mathrm{min}$ vs. $57 \pm 22 \mathrm{ml} / \mathrm{min})$ and it was more likely to suffer form ischemic heart disease $(81 \%$ and $85 \%$ vs. $66, \mathrm{p}=$ $0.02)$ and hypertension $(47 \%$ and $56 \%$ vs. $31 \%, \mathrm{p}=$ $0.006)$. The patients in Group C had higher NT-BNP levels comparing to the group A and B ( $383 \pm 385$ vs. $269 \pm 701$ and $251 \pm 290$ respectively, $\mathrm{p}=0.038$ ) and most of them had peripheral oedema (53\% vs. $18 \%$ and $23 \%$, p < $0.0001)$. No statistical significant differences in cardiac MRI measurements were noted in the 3 groups.

During a follow up period of $33 \pm 19$ months $10 \%$ of the patients form group A, 17 (27\%) from B and 15 (38\%) from $\mathrm{C}$ died suggesting an increased mortality in the patients with RAS $(\mathrm{p}=0.007)$. Applying multivariate Cox regression analysis and after adjustment for sex, age, GFR, diabetes mellitus, NYHA classification and EF, RAS ( $\mathrm{p}=$ 0.019, HR: $2.388,95 \%$ CI: $1.156-4.932)$, IHD ( $\mathrm{p}=0.015$, HR: 4.610, CI: 1.342-15.838), left ventricular end-diastolic volumes $(\mathrm{p}=0.010$, HR 1.009, CI 1.002-1.016) and non b-blocker treatment $(\mathrm{p}=0.060$, HR: 1.009 , CI $1.002-1.016$ ) were found to be independent predictors of mortality.

\section{Conclusion}

RAS is a common disease in patients with HF and is associated with increased mortality. Whether renal artery 
revascularisation will improve the prognosis in these patients needs further investigation.

Publish with Biomed Central and every scientist can read your work free of charge

"BioMed Central will be the most significant development for disseminating the results of biomedical research in our lifetime. " Sir Paul Nurse, Cancer Research UK

Your research papers will be:

- available free of charge to the entire biomedical community

- peer reviewed and published immediately upon acceptance

- cited in PubMed and archived on PubMed Central

- yours - you keep the copyright

Submit your manuscript here:

http://www.biomedcentral.com/info/publishing_adv.asp 